\title{
Prescribing antipsychotics for children and adolescents
}

\author{
Anthony C. James
}

\begin{abstract}
SUMMARY
The prescription of antipsychotic medication in children and adolescents ( $<18$ years of age) has increased immensely for a wide range of disorders including psychoses, bipolar disorder, conduct disorder, pervasive developmental disorder and obsessive-compulsive disorder. This has led to some concerns particularly as the evidence base in some areas is not strong, and antipsychotic medication - both first generation (FGA) and second generation (SGA) - is associated with considerable side-effects. Evidence from an increasing number of randomised controlled trials (RCTs) points to therapeutic efficacy with moderate to large effect sizes. However, some RCTs have a small number of participants, are of short duration, and many are industry funded. The use of antipsychotics alongside psychosocial interventions can be recommended in certain disorders, provided there is continued, careful monitoring. It is important to note, however, that for many conditions the use of antipsychotics is not licensed in the UK.
\end{abstract}

\section{DECLARATION OF INTEREST}

A.C.J. has received sponsorship from UCB Pharma.

There has been a huge increase in the prescription of antipsychotic medication to children and adolescents ( $<18$ years of age). ${ }^{a}$ However, there is a lack of empirical evidence to support an ever widening pattern of prescribing in this age group. In the USA, between 1999 and 2002 there was a sixfold increase in the prescription of antipsychotics to this population - $92 \%$ were second-generation antipsychotics (SGAs), and about a third (32\%) were prescribed for mood disorders (Olfson 2006). Despite the lack of formal indications, one study revealed that $12 \%$ of all SGA prescriptions were for children under age 9 years (Doey 2007), mostly for disruptive behavioural disorders.

This article assumes a thorough initial assessment of the patient, family and social circumstances. In only a few conditions such as psychosis is antipsychotic medication a first-line treatment. Antipsychotics, however, can be used in combination with other treatments such as cognitive-behavioural therapy (CBT), and always as part of a comprehensive treatment plan. Psychoeducation about the disorder, the effects and sideeffects of the medication is important, and may help with medication adherence.

An important issue is the licensing of SGAs in the UK. Risperidone and amisulpride are licensed for patients aged 15 or over, and clozapine for over-16s. A UK application for a licence for the use of risperidone for the management of severe aggression in autism was withdrawn by the drug company (Morgan 2007). With the adoption in 2007 of the European Union Regulation on Paediatric Medicines (Medicines and Healthcare products Regulatory Agency 2007), one hopes that clearer guidance will become available.

\section{Schizophrenia}

The evidence base demonstrating the efficacy of antipsychotic medication in the treatment of early-onset schizophrenia is relatively limited, but growing. A Cochrane review (Kennedy 2007) for childhood-onset schizophrenia (age at onset $<13$ years) found six studies (Table 1) with a total of 256 children and adolescents. The SGAs used were clozapine, risperidone and olanzapine. Although noting improvements with antipsychotic treatment, there was little to support the use of one antipsychotic over another, with the exception of clozapine over haloperidol. No superiority of SGAs over FGAs was found. A further systematic review and meta-analysis of 15 studies of antipsychotics in children and adolescents (up to the year 2003) showed a 55.7\% average response to SGAs compared with $72.3 \%$ for FGAs. The effect size of 0.36 in favour of the FGAs was not significant (Armenteros 2006). The review was limited by the methodological quality of the studies which included only two randomised controlled trials (RCTs) of FGAs - loxapine (Pool 1976) and haloperidol (Spencer 1992).

The recent US multicentre RCT, Treatment of Early-Onset Schizophrenia Spectrum Disorders (TEOSS; Sikich 2008), was designed to test whether SGAs are superior to FGAs in treating schizophrenia and schizoaffective disorder (Table 1). It was one of the largest studies involving 119 young people (aged 8-19 years). Results showed
Anthony C. James is a consultant child and adolescent psychiatrist and honorary senior lecturer at the University of Oxford. His research interests are in early-onset psychoses and bipolar disorder. Correspondence Dr Anthony C. James, Highfield Adolescent Unit, Warneford Hospital, Oxford OX3 7JX, UK. Email: anthony.james@ psych.ox.ac.uk

aClinicians should be aware of the limited licensing of different antipsychotics for children and adolescents. 
TABLE 1 Randomised controlled trials of antipsychotic medication for the treatment of schizophrenia

\begin{tabular}{|c|c|c|c|c|c|}
\hline Study & Participants & Treatment & Duration & Effectiveness & Adverse effects \\
\hline Faretra 1970 & $\begin{array}{l}n=60,87 \% \\
\text { childhood-onset } \\
\text { schizophrenia } \\
\text { Age } 5-12 \text { years }\end{array}$ & $\begin{array}{l}\text { Fluphenazine: up to } 1.25 \mathrm{mg} \\
\text { three times a day, } n=30 \\
\text { Haloperidol: up to } 1.25 \mathrm{mg} \\
\text { three times a day, } n=30\end{array}$ & 8 weeks & $\begin{array}{l}\text { CGI: no differences } \\
\text { fluphenazine v. haloperidol }\end{array}$ & $\begin{array}{l}\text { EPS, fluphenazine v. } \\
\text { haloperidol } \\
\text { Relative risk } 0.6(95 \% \mathrm{Cl} \\
0.21-2.13)\end{array}$ \\
\hline Engelhardt 1973 & $\begin{array}{l}n=30 \\
\text { Age } 6-12 \text { years }\end{array}$ & $\begin{array}{l}\text { Fluphenazine: mean } 10.4 \mathrm{mg} / \\
\text { day, } n=15 \\
\text { Haloperidol: mean } 10.4 \mathrm{mg} / \\
\text { day, } n=15\end{array}$ & 12 weeks & $\begin{array}{l}\text { Clinical Global Improvement } \\
\text { CPRS: no differences } \\
\text { fluphenazine v. haloperidol }\end{array}$ & $\begin{array}{l}\text { EPS, fluphenazine v. } \\
\text { haloperidol } \\
\text { Relative risk } 2.0(95 \% \mathrm{Cl} \\
0.5-2.46)\end{array}$ \\
\hline Pool 1976 & $\begin{array}{l}n=75 \\
\text { Mean age } \sim 15.5 \\
\text { years }\end{array}$ & $\begin{array}{l}\text { Loxapine } 87.5 \mathrm{mg} / \text { day } \\
\text { Haloperidol } 9.8 \mathrm{mg} / \mathrm{day} \\
\text { Placebo }\end{array}$ & 4 weeks & $\begin{array}{l}\text { Both treatments significantly } \\
\text { reduced BPRS total ratings } \\
\text { compared with placebo } \\
\text { No significant differences } \\
\text { observed between active } \\
\text { treatment groups }\end{array}$ & $\begin{array}{l}\text { EPS (e.g. muscle rigidity) } \\
\text { noted in } 19(73 \%) \text { of } 26 \\
\text { receiving loxapine and } \\
18(72 \%) \text { of } 25 \text { patients } \\
\text { receiving haloperidol } \\
\text { Sedation also problematic }\end{array}$ \\
\hline Realmuto 1984 & $\begin{array}{l}n=21 \\
\text { Mean age } \sim 15.5 \\
\text { years }\end{array}$ & $\begin{array}{l}\text { Thiothixene } 16.2 \mathrm{mg} \\
\text { Thioridazine } 178 \mathrm{mg}\end{array}$ & 6 weeks & $\begin{array}{l}\text { Both treatments significantly } \\
\text { reduced BPRS total scores }\end{array}$ & Marked sedation \\
\hline Spencer 1992 & $\begin{array}{l}n=16 \\
\text { Mean (s.d.) age: } \sim 8.9 \\
\text { years }\end{array}$ & $\begin{array}{l}\text { Crossover design: haloperidol } \\
1.8 \mathrm{mg} / \text { day v. placebo }\end{array}$ & 6 weeks & $\begin{array}{l}\text { CGI-I much/very much } \\
\text { improved: } 12(75 \%) \text { patients } \\
\text { of } 16 ; \text { marked reduction in } \\
\text { severity of persecutory ideation } \\
\text { and hallucinations }\end{array}$ & Sedation \\
\hline Kumra 1996 & $\begin{array}{l}n=21 \\
\text { Mean (s.d.) age: } 14.0 \\
\text { (2.3) years }\end{array}$ & $\begin{array}{l}\text { Clozapine } 176 \text { (149) mg/day } \\
\text { Haloperidol } 16 \text { (8) mg/day }\end{array}$ & 6 weeks & $\begin{array}{l}\text { Clozapine }>\text { haloperidol in } \\
\text { terms of positive (SAPS total) } \\
\text { and negative symptoms (SANS } \\
\text { total) }\end{array}$ & $\begin{array}{l}\text { Clozapine: high rates of } \\
\text { neutropenia and seizures }\end{array}$ \\
\hline Sikich 2004 & $\begin{array}{l}n=50, \text { broad } \\
\text { psychotic disorders } \\
\text { Mean (s.d.) age: } 14.7 \\
\text { (2.7) years }\end{array}$ & $\begin{array}{l}\text { Risperidone } 4(1.2) \mathrm{mg} / \mathrm{day} \\
\text { Olanzapine } 12.3(3.5) \mathrm{mg} / \text { day } \\
\text { Haloperidol } 5.0(2.0) \mathrm{mg} / \text { day }\end{array}$ & 8 weeks & $\begin{array}{l}\text { BPRS-C reduction > } 20 \% \text { : } \\
\text { risperidone } 74 \% \text {, olanzapine } \\
88 \% \text {, haloperidol } 54 \% \\
\text { All CGI-I much/very much } \\
\text { improved }\end{array}$ & $\begin{array}{l}\text { EPS and weight gain more } \\
\text { than reported in adult } \\
\text { studies }\end{array}$ \\
\hline Yao 2003 & $\begin{array}{l}n=42 \text { childhood- } \\
\text { onset schizophrenia } \\
\text { Mean age } \sim 11 \text { years }\end{array}$ & $\begin{array}{l}\text { Risperidone } 0.25-3 \mathrm{mg} / \mathrm{day} \\
n=21 \\
\text { Haloperidol } 0.5-12 \mathrm{mg} / \mathrm{day} \\
n=21\end{array}$ & 6 weeks & BPRS & $\begin{array}{l}\text { Risperidone fewer EPS than } \\
\text { haloperidol } \\
\text { Relative risk } 0.10(95 \% \mathrm{Cl} \\
0.03-0.36, \mathrm{NNT}=2(95 \% \\
\mathrm{Cl} 2-3)\end{array}$ \\
\hline Xiong 2004 & $\begin{array}{l}n=60 \\
\text { Age } 7-16 \text { years } \\
\text { Mean age } \sim 13 \text { years } \\
\text { Length of illness } \\
9-9.5 \text { years }\end{array}$ & $\begin{array}{l}\text { Risperidone } 0.5-5 \mathrm{mg} / \mathrm{day} \text {, } \\
n=30 \\
\text { Chlorpromazine } 50-400 \mathrm{mg} / \\
\text { day, } n=30\end{array}$ & 8 weeks & $\begin{array}{l}\text { BPRS: no improvement } \\
\text { No difference between } \\
\text { risperidone and chlorpromazine }\end{array}$ & $\begin{array}{l}\text { Restless } \\
\text { Relative risk } 1.5(95 \% \mathrm{Cl} \\
0.27-8.34)\end{array}$ \\
\hline Shaw 2006 & $\begin{array}{l}n=25 \\
\text { Mean age } \sim 12 \text { years }\end{array}$ & $\begin{array}{l}\text { Clozapine } 327(113) \mathrm{mg} / \text { day } \\
\text { Olanzapine } 18.1(4.3) \mathrm{mg} / \text { day }\end{array}$ & 8 weeks & $\begin{array}{l}\text { Clozapine > olanzapine } \\
\text { improvement in negative } \\
\text { symptoms (SANS) }\end{array}$ & $\begin{array}{l}\text { Marked weight gain at } 4 \mathrm{~kg} \\
\text { during the } 8 \text {-week trial noted } \\
\text { in both groups. At 2-year } \\
\text { follow-up, } 6(40 \%) \text { of } 15 \\
\text { patients were observed to } \\
\text { have dyslipidaemia }\end{array}$ \\
\hline Kumra 2008 & $\begin{array}{l}n=39 \\
\text { Mean (s.d.) age: } 15.6 \\
\text { (2.1) years }\end{array}$ & $\begin{array}{l}\text { Clozapine } 403.1 \text { (201.8) } \\
\mathrm{mg} / \mathrm{day} \\
\text { Olanzapine } 26.2 \text { (6.5) mg/day }\end{array}$ & 12 weeks & $\begin{array}{l}>30 \% \text { BPRS reduction: } 66 \% \\
\text { clozapine, } 33 \% \text { olanzapine } \\
\text { Clozapine > 'high-dose' } \\
\text { olanzapine negative symptoms } \\
\text { (SANS) } \\
\text { CGI much/very much improved }\end{array}$ & $\begin{array}{l}\text { Weight gain } \\
\text { High incidence of } \\
\text { dyslipidaemia }\end{array}$ \\
\hline $\begin{array}{l}\text { Kryzhanovskaya } \\
2009\end{array}$ & $\begin{array}{l}n=107 \\
\text { Mean (s.d.) age: } 16.2 \\
\text { (1.3) years }\end{array}$ & $\begin{array}{l}\text { Olanzapine } 11.1(4.0) \mathrm{mg} / \text { day } \\
\text { v. placebo }\end{array}$ & 6 weeks & $\begin{array}{l}\text { Olanzapine }>\text { placebo in terms } \\
\text { of improvement from baseline } \\
\text { to end-point on the BPRS-C } \\
(P=0.003) \text { and CGI-S }(P=0004) \\
\text { respectively } \\
\text { Treatment response rate was } \\
\text { not significantly different } \\
\text { between olanzapine }(37.5 \%) \\
\text { and placebo }(25.7 \%)\end{array}$ & $\begin{array}{l}\text { Mean weight gain } 4.3 \\
\text { (3.3) } \mathrm{kg} \text { with olanzapine }\end{array}$ \\
\hline
\end{tabular}




\begin{tabular}{|c|c|c|c|c|c|}
\hline Study & Participants & Treatment & Duration & Effectiveness & Adverse effects \\
\hline Sanford 2007 & $\begin{array}{l}n=302 \\
\text { Mean age } 15.5 \text { years } \\
\text { (range } 13-17 \text { ) }\end{array}$ & $\begin{array}{l}\text { Aripiprazole } 10 \mathrm{mg} / \text { day, } \\
\text { aripiprazole } 30 \mathrm{mg} / \text { day v. } \\
\text { placebo }\end{array}$ & 6 weeks & $\begin{array}{l}\text { Aripiprazole ( } 10 \mathrm{mg} \text { and } 30 \mathrm{mg} \\
\text { doses) > placebo improvement } \\
\text { from baseline to end-point on } \\
\text { the PANSS }\end{array}$ & $\begin{array}{l}\text { Mild to moderate severity } \\
\text { Extrapyramidal disorder, } \\
\text { somnolence, akathisia }\end{array}$ \\
\hline Haas 2009b & $\begin{array}{l}n=257 \\
\text { Age } 13-17 \text { years }\end{array}$ & $\begin{array}{l}\text { Risperidone low dose } \\
0.15-1.6 \mathrm{mg} / \text { day }(n=132) \\
\text { v. high dose } 1.5-6.0 \mathrm{mg} / \text { day } \\
\text { ( } n=125) \text { risperidone }\end{array}$ & 8 weeks & $\begin{array}{l}\text { PANSS total score } \\
\text { improvement (mean (s.d.)) was } \\
\text { significantly }(P<0.001) \text { greater } \\
\text { with high- }(-23.6(22.8)) \text { v. low- } \\
\text { dose }(-12.5(20.3)) \text { risperidone }\end{array}$ & $\begin{array}{l}\text { All adverse events }>\text { with } \\
\text { high dose, e.g. hypertonia } \\
4.5 \% \text { low dose v. } 14.4 \% \\
\text { high dose }\end{array}$ \\
\hline Sikich 2008 & $\begin{array}{l}n=119 \text { : } \\
\text { schizophrenia } 66 \% \text {, } \\
\text { schizoaffective } 34 \%\end{array}$ & $\begin{array}{l}\text { Olanzapine } 2.5-20 \mathrm{mg} / \text { day, } \\
\text { risperidone } 0.5-6.0 \mathrm{mg} / \text { day or } \\
\text { molindone } 10-140 \mathrm{mg} / \text { day + } \\
\text { benztropine } 1 \mathrm{mg} / \text { day }\end{array}$ & 8 weeks & $\begin{array}{l}\text { No significant differences in } \\
\text { response rates: molindone } \\
50 \% \text {, olanzapine } 34 \% \text {, } \\
\text { risperidone } 46 \%\end{array}$ & $\begin{array}{l}\text { Olanzapine significant } \\
\text { weight gain and lipid } \\
\text { changes }\end{array}$ \\
\hline
\end{tabular}

BPRS, Brief Psychiatric Rating Scale; BPRS-C, Brief Psychiatric Rating Scale for Children; CPRS, Children's Psychiatric Rating Scale; CGI, Clinical Global Impression scale; CGI-I, Clinical Global Impression scale - Improvement; CGI-S, Clinical Global Impression scale - Severity; EPS, extrapyramidal symptoms; NNT, number needed to treat; PANSS, Positive and Negative Syndrome Scale; SANS, Scale for the Assessment of Negative Symptoms; SAPS, Scale for the Assessment of Positive Symptoms.

that risperidone and olanzapine (SGAs) were not superior to the FGA molindone. Given the sideeffect profile of SGAs, particularly weight gain and metabolic problems, the authors questioned the current, almost exclusive, use of SGAs to treat early-onset schizophrenia and schizoaffective disorder. Indeed, given the similar findings of a lack of superiority of SGAs over FGAs in two large pragmatic trials for adults with schizophrenia (CATIE and CUtLAS; Lewis 2008), there are questions about the National Institute for Health and Clinical Excellence (NICE) guidelines (National Collaborating Centre for Mental Health 2002) recommending SGAs as first-line treatment.

\section{Mixed dopamine agonists and antagonists}

According to the dopamine hypothesis of schizophrenia, it is an excess of dopamine in the mesolimbic system which is responsible for increased salience being given to insignificant events and thoughts (Kapur 2003), and which ultimately leads to the development of psychotic symptoms. Alongside this dopamine excess in the mesolimbic system there is a relative dopamine deficiency in the frontal lobes. The finding of a hypo- and hyperdopaminergic state has led to the development of mixed dopamine agonists and antagonists such as aripiprazole. Aripiprazole was designed to reduce dopamine overactivity in the mesolimbic system while purportedly increasing dopamine underactivity in frontal lobe projections. Preliminary evidence for its efficacy in adolescents comes from a short-term RCT (6 weeks) (Sanford 2007) of aripiprazole v. placebo.

\section{Cognition}

Despite the claims of cognitive enhancement with SGAs, the evidence is weak. For example, methodological problems of earlier studies include the lack of a control group. Recent work suggests that some of the improvements in cognition in the firstepisode schizophrenia group may have been due to practice effects (i.e. exposure, familiarity, and/or procedural learning) (Goldberg 2007). Differential medication effects on cognition appear small.

\section{Clozapine}

Various RCTs have shown clozapine to be more effective than haloperidol (Kumra 1996), olanzapine (Shaw 2006) and high-dose olanzapine (Kumra 2008) (Box 1). Clozapine is effective against both positive and negative symptoms of schizophrenia. (Kumra 2008). Improvement with clozapine is seen within the first 6 weeks of treatment and is related to the plasma concentrations of $\mathrm{N}$-desmethylclozapine (NDMC)/clozapine ratio (Sporn 2007). Unfortunately, as with nearly all antipsychotics, the rate of side-effects in children and adolescents is higher than that typically found in the adult population. Interestingly, the sideeffects do not appear to be related to clozapine dose, clozapine or NDMC plasma concentrations, or NDMC/clozapine ratio. Overall, clozapine appears

\section{BOX 1 First- and second-generation antipsychotics}

- First-generation antipsychotics such as chlorpromazine, introduced in the 1950s, were thought to work by reducing dopamine overactivity in the mesolimbic pathways via blockade of $D_{2}$ receptors

- Second-generation antipsychotics such as risperidone and olanzapine, introduced in the 1970s, were designed to be similar to clozapine, a superior antipsychotic, but with fewer side-effects. They have lower dopamine $D_{2}$ receptor affinity and higher affinity for serotonergic $5-\mathrm{HT}_{2 \mathrm{~A}}$ receptors 
to be a uniquely beneficial second-line agent for treating children with refractory schizophrenia (Gogtay 2008), and some argue for its early use in first-episode psychosis (Agrid 2007).

\section{Pharmacokinetics}

For clozapine and olanzapine, the pharmacokinetic profile varies greatly between individuals. The metabolism of olanzapine and clozapine is higher in males and in those who smoke (Bigos 2008). It is thought that aromatic polycarbons produced by smoking induce liver enzymes. The serum concentrations of olanzapine and olanzapine metabolites in adolescents show high intra-individual variability (1.04- to 10.7-fold, dose-corrected) (Bachmann 2008). For olanzapine, the daily dose, number of co-medications, body mass index and age all affect the variability of dose-corrected olanzapine serum concentrations (all $P<0.001$ ). Monitoring of plasma levels is indicated, especially if there is doubt about the therapeutic response.

\section{Bipolar disorder}

There is an increasing trend to use antipsychotics in children and adolescents with bipolar disorder, both in the acute manic phase and as mood stabilisers (Olfson 2006), although the evidence base for this age group relies largely upon open trials and case reports. A small, double-blind, placebo-controlled study found that quetiapine in combination with divalproex was more effective for the treatment of adolescent bipolar mania than divalproex alone (DelBello 2002), while separately, quetiapine appears to act faster than divalproex (DelBello 2006) (Table 2). A short-term (3 weeks) multicentre double-blind RCT involving out-patient and in-patient adolescents aged 13-17 years with an acute manic or mixed episode (Tohen 2007) showed a significant benefit of olanzapine over placebo in reducing Young Mania Rating Scale scores (effect size 0.84). Risperidone also appears effective in the manic stage of the illness (Haas 2009a) (Table 2).

Expert guidelines on the treatment of paediatric bipolar disorder (Kowatch 2005) recommend the use of mood stabilisers or SGAs. A combination of mood stabilisers and SGAs is advocated in some cases. Indeed, polypharmacy has become more common. The choice of medication depends on the phase of the illness, presence of psychosis, presence of rapid cycling, risk of side-effects and, crucially, patient and family acceptance. Second-generation antipsychotics are recommended for treating psychotic symptoms but they also act as mood stabilisers. It is important to note that premature discontinuation of antipsychotic medication leads to a recurrence of psychotic symptoms in a large percentage of cases (Kafantaris 2001).

According to expert consensus guidelines (Kowatch 2005), both clozapine and electroconvulsive therapy are considered treatments of last resort. It is suggested that clozapine be reserved for patients with bipolar disorder who have failed to respond adequately to at least two trials of a combination treatment regimen that includes at least two of the following: lithium, an anticonvulsant, and an antipsychotic.

\section{Depression}

According to the NICE guidelines (National Institute for Health and Clinical Excellence 2005), the treatment for mild cases of juvenile depression

Randomised controlled trials of antipsychotic medication for the treatment of bipolar disorder

\begin{tabular}{|c|c|c|c|c|c|}
\hline Study & Participants & Treatment & Duration & Effectiveness & Adverse effects \\
\hline DelBello 2002 & $\begin{array}{l}n=30, \text { bipolar } I \text { disorder, } \\
\text { mixed or manic } \\
\text { YMRS score }>20 \\
\text { Mean age } 14.3 \text { years }\end{array}$ & $\begin{array}{l}\text { Divalproex } 20 \mathrm{mg} / \mathrm{kg}+ \\
\text { quetiapine } 450 \mathrm{mg} / \mathrm{day} \\
\text { or placebo }\end{array}$ & 6 weeks & $\begin{array}{l}\text { More patients showed greater YMRS } \\
\text { improvements with addition of } \\
\text { quetiapine }(87 \%) \text { than placebo }(53 \%) \\
(P<0.05)\end{array}$ & $\begin{array}{l}\text { No EPS } \\
\text { Sedation: quetiapine } \\
80 \% \text { v. placebo } 33 \%\end{array}$ \\
\hline DelBello 2006 & $\begin{array}{l}n=50, \text { bipolar I disorder, } \\
\text { manic, mixed }\end{array}$ & $\begin{array}{l}\text { Quetiapine } 400-600 \mathrm{mg} / \\
\text { day v. divalproex }\end{array}$ & 4 weeks & $\begin{array}{l}\text { No differences in YMRS improvement } \\
\text { Quetiapine faster onset of action }\end{array}$ & $\begin{array}{l}\text { Sedation, dizziness and } \\
\text { gastrointestinal upset } \\
30-60 \%\end{array}$ \\
\hline Tohen 2007 & $\begin{array}{l}n=160,107 \text { placebo } \\
\text { Mean age } 15.1 \text { years } \\
\text { (s.d. }=1.3 \text { ) }\end{array}$ & $\begin{array}{l}\text { Olanzapine } 2.5-20 \mathrm{mg} / \\
\text { day v. placebo }\end{array}$ & 3 weeks & $\begin{array}{l}\text { The mean baseline to LOCF } \\
\text { end-point change in the YMRS total } \\
\text { olanzapine > placebo }-7.65 \text { v. }-9.99 \text {, } \\
P<0.001 \text {; effect size } 0.84\end{array}$ & $\begin{array}{l}\text { Weight gain; rise in } \\
\text { hepatic enzymes and } \\
\text { prolactin in olanzapine } \\
\text { group }\end{array}$ \\
\hline Haas 2009a & $\begin{array}{l}n=169 \\
\text { Age } 10-17 \text { years }\end{array}$ & $\begin{array}{l}\text { Risperidone low dose } \\
0.5-2.5 \mathrm{mg} / \text { day }(n=50) \\
\text { v. high dose } 3-6 \mathrm{mg} / \text { day } \\
\text { ( } n=61) \text { v. placebo }(n=58)\end{array}$ & 3 weeks & $\begin{array}{l}\text { Mean (s.d.) improvement in YMRS } \\
\text { total score was greater in both } \\
\text { risperidone groups }(0.5-2.5 \mathrm{mg}:-18.5 \\
(9.7) ; 3-6 \mathrm{mg}:-16.5(10.3)) \text { v. placebo } \\
(-9.1(11.0))(P<0.001)\end{array}$ & $\begin{array}{l}\text { Somnolence: } 19 \% \\
\text { placebo v. } 42 \% \text { low dose } \\
\text { and } 52 \% \text { high dose }\end{array}$ \\
\hline
\end{tabular}

EPS, extrapyramidal symptoms; LOCF, last observation carried forward; YMRS, Young Mania Rating Scale. 
consists of brief psychosocial interventions followed by a trial of CBT and then antidepressant medication, if required. The ADAPT study (Goodyer 2007), however, points to the earlier use of selective serotonin reuptake inhibitors (SSRIs) for moderate to severe depression, with little benefit seemingly conferred by the addition of CBT.

The effects of SGAs on serotonin (5-HT) receptors - as $5-\mathrm{HT}_{2 \mathrm{~A}}$ and $5-\mathrm{HT}_{2 \mathrm{C}}$ antagonists, and as a partial $5-\mathrm{HT}_{1 \mathrm{~A}}$ agonist in the case of aripiprazole - suggest that this class of drugs may be useful in treating depression. Available evidence from randomised placebo-controlled trials involving adults supports the partial effectiveness of olanzapine and quetiapine as augmenters of SSRIs in treatment-resistant depression (defined as a failure to respond to at least one adequate trial of an antidepressant) (Shelton 2008). For children and adolescents, however, such evidence is at present lacking.

\section{Pervasive developmental disorder}

It is generally held that there are no indications for the use of antipsychotics in treating the core symptoms of autism or pervasive developmental disorder. However, the Research on Pediatric Psychopharmacology Autism Network (McDougle 2005) showed improvements in the areas of sensory motor behaviours, affectual reactions and sensory responses in children with autism given risperidone (Table 3). Small-scale RCTs point to a significantly greater reduction in sensory motor and language subscale scores on the Ritvo-Freeman Real Life Rating Scale with risperidone v. haloperidol (Miral 2008), and an improvement in divided attention in young children with autism prescribed risperidone (Troost 2005) (Table 3). However, the main indication for the use of antipsychotics appears to be to control temper tantrums, irritability, aggression and rapid mood changes. Six RCTs support the use of risperidone in reducing these behaviours (Chavez 2007). An RCT of olanzapine (Hollander 2006) found an overall improvement on the Clinicians Global Impressions-Improvement (CGI-I) scale, but no changes in aggression or irritability. There is less evidence supporting the use of other SGAs such as ziprasidone and aripiprazole (Chavez 2007). A small RCT by Luby et al (2006) pointed to the relative safety of risperidone in the pre-school population (children under 5 years old), which is important as this is an age group likely to be targeted for this developmental disorder.

\section{Conduct disorder}

Conduct disorder is often associated with psychosocial stressors and adversity. Environmental, social and psychological interventions are therefore the first line of treatment. Treatment of comorbid conditions such as attention-deficit hyperactivity disorder, which may require medication, is important; however, antipsychotic medication for 'pure' conduct disorder is not often used in routine clinical practice in the UK.

For children admitted to hospital with severe aggression and conduct disorder, both lithium and haloperidol (dose 1-6mg/day) reduce aggression (Campbell 1984); however, there are notable sideeffects with both drugs. Double-blind controlled studies show that risperidone is effective in reducing symptoms (Table 4), with effect sizes ranging from 0.6 (medium) to 1.5 (very large) (Jensen 2007). However, the RCTs share methodological problems of small trial numbers, high drop-out rates, and selection issues, with most children having low IQs. Nevertheless, when an improvement occurs, it does so in the first 2 weeks of treatment. An important question is the length of treatment, as withdrawal may lead to a recurrence of symptoms. Long-term maintenance therapy with risperidone appears effective, with few reported adverse effects (Jensen 2007).

There are no NICE guidelines for pharmacological treatments of conduct disorder; instead, parent training is advocated (National Institute for Health and Clinical Excellence 2006). Overall, with children and adolescents medication should be reserved for those whom psychosocial treatments have failed or for whom they have proved inadequate. For severe aggression, a trial of medication may then be appropriate.

\section{Tourette syndrome and tics}

As a treatment rationale for Tourette syndrome and tics, antipsychotics are thought to act primarily by blocking dopamine receptors, thus decreasing dopaminergic input from the substantia nigra and ventral tegmentum to the basal ganglia. Pimozide and haloperidol are effective (Sallee 1997); however, both have serious side-effects haloperidol producing extrapyramidal symptoms, and pimozide prolonging the QT interval with associated risk of a fatal ventricular arrhythmia. Randomised controlled trials have shown risperidone to be superior to placebo (Scahill 2003), equally effective as clonidine - an alpha adrenergic agonist (Gaffney 2002) - and superior to pimozide (Gilbert 2004). Doses ranging from 1.0 to $2.5 \mathrm{mg} /$ day are effective and neurological side-effects rare. Ziprasidone is also effective (Sallee 2000), although cardiac side-effects with QT prolongation are concerning. These trials are limited by small numbers and short duration (Table 3). 


\begin{tabular}{|c|c|c|c|c|c|}
\hline Study & Participants & Treatment & Duration & Effectiveness & Adverse effects \\
\hline \multicolumn{6}{|c|}{$\begin{array}{l}\text { Pervasive developmental } \\
\text { disorder }\end{array}$} \\
\hline McCracken 2002 & $\begin{array}{l}n=101 \text { with autism } \\
\text { Mean age } 9.2 \text { years } \\
\text { Age range } 5-17 \text { years }\end{array}$ & $\begin{array}{l}\text { Risperidone } 1.8 \\
\text { (0.7) } \mathrm{mg} / \mathrm{day}(n=49) \\
\text { v. placebo }(n=52)\end{array}$ & 8 weeks & $\begin{array}{l}\text { Mean (s.d.) ABC-I score: } 56.9 \% \\
\text { decrease with risperidone (from } \\
26.2(7.9) \text { at baseline to } 11.3(7.4) \\
\text { at } 8 \text { weeks v. } 14.1 \% \text { decrease with } \\
\text { placebo (from } 25.5(6.6) \text { to } 21.9 \\
(9.5))(P<0.001) \\
\text { Effect size }-1.2\end{array}$ & $\begin{array}{l}\text { Tiredness during the day } \\
(P<0.0001) \text {, excessive appetite } \\
(P<0.0001) \text {, difficulty waking } \\
(P<0.05) \text {, excessive saliva or } \\
\text { drooling }(P=0.04) \text {, and dizziness or } \\
\text { loss of balance }(P=0.04) \text {, increased } \\
\text { appetite }(73 \%) \text {, fatigue }(59 \%) \text {, } \\
\text { drowsiness }(49 \%) \text {. Weight gain } \\
2.7 \mathrm{~kg} \text { risperidone v. } 0.8 \mathrm{~kg} \text { placebo }\end{array}$ \\
\hline Shea 2004 & $\begin{array}{l}n=79: \operatorname{PDD} n=41 \\
\text { controls } n=39 \\
\text { Mean age } 7.5 \text { years }\end{array}$ & $\begin{array}{l}\text { Risperidone } 1.17 \\
(0.7) \mathrm{mg} / \text { day }\end{array}$ & 8 weeks & $\begin{array}{l}\text { Mean ABC-I score: with } \\
\text { risperidone decrease from } 18.9 \\
\text { at baseline to } 6.8 \text { at end-point; } \\
\text { placebo } 21.2 \text { to } 14.7(P<0.001) \\
\text { Effect size }-0.8\end{array}$ & $\begin{array}{l}\text { Somnolence: } 72.5 \% \text { risperidone v. } \\
7.7 \% \text { placebo } \\
\text { Mean weight gain } 2.7 \mathrm{~kg} \mathrm{v} \text { v. } 1.0 \mathrm{~kg} \\
\text { EPS: tremor, hypokinesia, increased } \\
\text { systolic blood pressure, tachycardia }\end{array}$ \\
\hline Nagaraj 2006 & $\begin{array}{l}n=39 \text { with autism } \\
\text { Age range } 2-9 \text { years }\end{array}$ & $\begin{array}{l}\text { Risperidone } 0.5 \mathrm{mg} / \\
\text { day for } 2 \text { weeks } \\
\text { then } 1 \mathrm{mg} / \text { day }\end{array}$ & 6 months & $\begin{array}{l}>20 \% \text { improvement on the CARS: } \\
\text { risperidone } 12 / 19 \text { v. placebo } 0 / 20 \text {, } \\
P<0.001\end{array}$ & Sedation \\
\hline Troost 2005 & $\begin{array}{l}n=24 \text { with } \mathrm{PDD} \\
\text { Age range } 5-17 \text { years }\end{array}$ & $\begin{array}{l}\text { Risperidone } \\
\text { discontinuation }\end{array}$ & 8 weeks & $\begin{array}{l}8 / 12 \text { risperidone relapsed v. } 3 / 12 \\
\text { placebo, } P=0.04\end{array}$ & $\begin{array}{l}\text { Weight gain of } 5.7 \mathrm{~kg} \text { with } \\
\text { risperidone }\end{array}$ \\
\hline Hollander 2006 & $\begin{array}{l}n=11 \text { with PPD } \\
\text { Age } 6-14 \text { years }\end{array}$ & $\begin{array}{l}\text { Olanzapine mean } \\
\text { (s.d.) dose: } 10 \\
\text { (2) } \mathrm{mg} / \text { day }\end{array}$ & 8 weeks & $\begin{array}{l}\text { CGI-I: } 50 \% \text { on olanzapine v. } 20 \% \\
\text { on placebo were responders }\end{array}$ & $\begin{array}{l}\text { Weight gain } 3.3 \mathrm{~kg} \text { on olanzapine } \mathrm{v} \text {. } \\
0.9 \mathrm{~kg} \text { placebo }\end{array}$ \\
\hline Luby 2006 & $\begin{array}{l}n=23 \text { with } A S D \\
\text { Age } 2.5-6 \text { years }\end{array}$ & $\begin{array}{l}\text { Risperidone } \\
0.5-1.5 \mathrm{mg} / \text { day } \\
(n=11) \text { v. placebo } \\
(n=12)\end{array}$ & 6 months & $\begin{array}{l}\text { No significant differences in } \\
\text { autism severity scores }\end{array}$ & $\begin{array}{l}\text { Weight gain and } \\
\text { hyperprolactinaemia }\end{array}$ \\
\hline Miral 2008 & $\begin{array}{l}n=28 \text { with autism } \\
\text { Age } 7-17 \text { years }\end{array}$ & $\begin{array}{l}\text { Risperidone mean } \\
\text { (s.d.) dose: } 2.6 \\
\text { (1.3) } \mathrm{mg} / \mathrm{day}(n=13) \\
\text { Haloperidol } 2.6 \\
(0.8) \mathrm{mg} / \text { day }(n=15)\end{array}$ & 10 weeks & $\begin{array}{l}\text { Reduction from baseline in } \\
\text { Ritvo-Freeman Real Life Rating } \\
\text { Scale, sensory motor (subscale I) } \\
\text { and language (subscale V) scores, } \\
\text { risperidone }>\text { haloperidol }(P<0.05 \text { ) } \\
\text { ABC and Turgay DSM-IV PDD } \\
\text { reduction in scale scores, } \\
\text { risperidone }>\text { haloperidol }(P<0.05 \\
\text { and } P<0.01 \text { respectively) }\end{array}$ & Few EPS \\
\hline \multicolumn{6}{|c|}{ Tourette syndrome/tics } \\
\hline Sallee 1997 & $\begin{array}{l}n=22 \\
\text { Age } 7-16 \text { years }\end{array}$ & $\begin{array}{l}\text { Pimozide } 3.4 \\
\text { (1.6) mg/day v. } \\
\text { haloperidol } 3.5 \\
\text { (2.2) } \mathrm{mg} / \text { day v. } \\
\text { placebo }\end{array}$ & $\begin{array}{l}24 \text { weeks } \\
\text { crossover } \\
\text { trial }\end{array}$ & $\begin{array}{l}\text { Pimozide }>\text { placebo } P=0.05 \\
\text { Tourette syndrome/tic subscale } \\
\text { score } 26 \\
\text { Effect size } 0.5 \\
\text { Haloperidol v. placebo: } P \text { not } \\
\text { significant } \\
\text { Effect size } 0.3\end{array}$ & $\begin{array}{l}41 \% \text { of those on haloperidol } \\
\text { experienced side-effects, mainly } \\
\text { EPS }\end{array}$ \\
\hline Sallee 2000 & $\begin{array}{l}n=28 \\
\text { Mean age } 11.5 \text { years }\end{array}$ & $\begin{array}{l}\text { Ziprasidone } \\
28.2 \mathrm{mg} / \text { day }(n=16) \\
\text { v. placebo }(n=12)\end{array}$ & 8 weeks & $\begin{array}{l}\text { Tic severity: }-39 \% \text { ziprasidone v. } \\
-16 \% \text { placebo }(P=0.02) \\
\text { Effect size }-0.8\end{array}$ & $\begin{array}{l}\text { Weight gain } 0.7 \mathrm{~kg} \text { ziprasidone } \mathrm{v} \text {. } \\
0.8 \mathrm{~kg} \text { placebo }\end{array}$ \\
\hline Gaffney 2002 & $n=21$ & $\begin{array}{l}\text { Risperidone } 1.5 \mathrm{mg} / \\
\text { day }(n=9) \\
\text { Clonidine } 0.18 \mathrm{mg} / \\
\text { day }(n=12)\end{array}$ & 8 weeks & $\begin{array}{l}\text { Response similar in both groups } \\
\text { Tics reduced: } 21 \% \text { risperidone v. } \\
26 \% \text { clonidine }\end{array}$ & $\begin{array}{l}\text { Weight gain: } 2.1 \mathrm{~kg} \text { risperidone } \mathrm{v} \text {. } \\
0.1 \mathrm{~kg} \text { clonidine } \\
\text { Sedation: clonidine > risperidone }\end{array}$ \\
\hline Scahill 2003 & $\begin{array}{l}n=26 \\
\text { Mean age } 11.1 \text { years }\end{array}$ & $\begin{array}{l}\text { Risperidone } 2.5 \mathrm{mg} / \\
\text { day }(n=12) \mathrm{v} \text {. } \\
\text { placebo }(n=14)\end{array}$ & 8 weeks & $\begin{array}{l}\text { Tic severity reduced: } 36 \% \\
\text { risperidone v. } 9 \% \text { placebo } \\
(P<0.01) \text {; effect size } 1.0\end{array}$ & $\begin{array}{l}\text { No EPS } \\
\text { Weight gain: } 2.8 \mathrm{~kg} \text { risperidone v. } \\
0 \text { kg placebo }\end{array}$ \\
\hline Gilbert 2004 & $\begin{array}{l}n=9 \\
\text { Mean age } 11 \text { years }\end{array}$ & $\begin{array}{l}\text { Crossover: } \\
\text { risperidone } 2.5 \mathrm{mg} / \\
\text { day and pimozide } \\
2.4 \mathrm{mg} / \text { day }\end{array}$ & 4 weeks & $\begin{array}{l}\text { Greater reduction in tic severity } \\
\text { with risperidone }(42 \%) \text { v. pimozide } \\
(21 \%), P=0.05\end{array}$ & $\begin{array}{l}\text { Weight gain: } 1.9 \mathrm{~kg} \text { risperidone } \mathrm{v} \text {. } \\
1.0 \mathrm{~kg} \text { pimozide }\end{array}$ \\
\hline
\end{tabular}

ABC, Aberrant Behaviour Checklist; ABC-I, Aberrant Behaviour Checklist - Irritability subscale; ASD, autism-spectrum disorders; CARS, Childhood Autism Rating Scale; CGI-I, Clinical Global Impression scale - Improvement; EPS, extrapyramidal symptoms; PDD, pervasive developmental disorders. 
TABLE 4 Randomised controlled trials of antipsychotic medication for the treatment of disruptive behaviour disorders

\begin{tabular}{|c|c|c|c|c|c|}
\hline Study & Participants & Treatment & Duration & Effectiveness & Adverse effects \\
\hline Findling 2000 & $\begin{array}{l}n=20 \text { : conduct disorder } \\
n=10, \text { controls } n=10 \\
\text { Mean } 9.2 \text { years }\end{array}$ & Risperidone $0.03 \mathrm{mg} / \mathrm{kg}$ & 10 weeks & $\begin{array}{l}\text { RAAPP score: }-1.7 \text { risperidone v. } \\
-0.2 \text { placebo }(P<0.05) \\
\text { CGl: }-2.6 \text { risperidone v. }-0.1 \\
\text { placebo }(P<0.01) \\
\text { Effect size }-1.0\end{array}$ & $\begin{array}{l}\text { No EPS } \\
\text { Weight gain: } 4.2 \mathrm{~kg} \\
\text { risperidone v. } 0.7 \mathrm{~kg} \text { placebo } \\
(P<0.01)\end{array}$ \\
\hline Buitelaar 2001 & $\begin{array}{l}n=38: \mathrm{DBD} / \mathrm{ADHD} n=19 \\
\text { controls } n=19 \\
\text { Mean age } 14 \text { years } \\
\text { I0 60-90 }\end{array}$ & $\begin{array}{l}\text { Risperidone } 2.9 \\
(0.04) \mathrm{mg} / \text { day v. placebo }\end{array}$ & 6 weeks & $\begin{array}{l}\text { CGI score: }-1.6 \text { risperidone } v .+0.2 \\
\text { placebo }(P<0.001) \\
\text { Effect size }-1.5 \\
\text { ABC significantly improved with } \\
\text { risperidone }(P<0.05)\end{array}$ & $\begin{array}{l}\text { Risperidone: no or mild EPS } \\
\text { Weight gain: } 2.3 \mathrm{~kg} \\
\text { risperidone v. } 0.6 \mathrm{~kg} \text { placebo } \\
(P<0.05)\end{array}$ \\
\hline $\begin{array}{l}\text { Van Bellinghen } \\
2001\end{array}$ & $\begin{array}{l}n=14: \text { DBD } n=7 \text {, controls } \\
n=7 \\
\text { Age } 6-14 \text { years } \\
\text { I0 } 45-85\end{array}$ & $\begin{array}{l}\text { Risperidone } 1.2 \\
(0.05) \mathrm{mg} / \text { day v. placebo }\end{array}$ & 4 weeks & $\begin{array}{l}\text { ABC score improvement in } 65 \% \\
\text { risperidone v. } 7 \% \text { placebo }\end{array}$ & $\begin{array}{l}\text { EPS similar with risperidone } \\
\text { and placebo } \\
\text { Weight gain: } 1.8 \mathrm{~kg} \\
\text { risperidone v. } 0.6 \mathrm{~kg} \text { placebo } \\
(P=0.319)\end{array}$ \\
\hline Snyder 2002 & $\begin{array}{l}n=110: \text { DBD } n=53 \\
\text { controls } n=57 \\
\text { Mean age } 8.7 \text { years } \\
\text { I0 36-84 }\end{array}$ & $\begin{array}{l}\text { Risperidone } 0.98 \\
(0.03) \mathrm{mg} / \text { day v.placebo }\end{array}$ & 6 weeks & $\begin{array}{l}\mathrm{N}-\mathrm{CBRF} \text { conduct scale score: } \\
-15.8 \text { risperidone v. }-6.8 \text { placebo } \\
(P<0.001) \\
\text { Effect size }-0.6\end{array}$ & $\begin{array}{l}\text { Hypertonia: } 8 \% \text { risperidone v. } \\
2 \% \text { placebo } \\
\text { Somnolence: } 42 \% \text { v. } 14 \% \\
\text { Weight gain: } 2.2 \mathrm{~kg} \mathrm{v.} 0.2 \mathrm{~kg}\end{array}$ \\
\hline Aman 2002 & $\begin{array}{l}n=118: \text { DBD } n=55 \\
\text { controls } n=63 \\
\text { Age } 5-2 \text { years } \\
\text { I0 } 36-84\end{array}$ & $\begin{array}{l}\text { Risperidone } 1.2 \\
(0.04) \mathrm{mg} / \text { day v. placebo }\end{array}$ & 6 weeks & $\begin{array}{l}\mathrm{N}-\mathrm{CBRF} \text { conduct scale score: } \\
-15.2 \text { risperidone } \mathrm{v} .-6.2 \text { placebo } \\
(P<0.01) \\
\text { Effect size }-0.8 \\
\mathrm{BPI} \text { aggressive scale: }-6.8 \\
\text { risperidone v. }-2.4 \text { placebo } \\
(P<0.01)\end{array}$ & $\begin{array}{l}\text { Low EPS: risperidone = } \\
\text { placebo } \\
\text { Weight gain: } 15 \%(2.2 \mathrm{~kg}) \mathrm{v} \text {. } \\
2 \%(0.9 \mathrm{~kg})\end{array}$ \\
\hline Hollander 2006 & $\begin{array}{l}n=11 \\
\text { Age } 6-14 \text { years }\end{array}$ & $\begin{array}{l}\text { Olanzapine mean (s.d.) } \\
\text { dose: } 10(2) \mathrm{mg} / \text { day }\end{array}$ & 8 weeks & $\begin{array}{l}\text { CGI-I: } 50 \% \text { on olanzapine v. } 20 \% \\
\text { on placebo were responders }\end{array}$ & $\begin{array}{l}\text { Weight gain: } 3.3 \mathrm{~kg} \text { on } \\
\text { olanzapine v. } 0.9 \mathrm{~kg} \text { placebo }\end{array}$ \\
\hline Reyes 2006 & $\begin{array}{l}n=335: \text { DBD } n=172 \\
\text { controls } n=163 \\
\text { Mean age } 11 \text { years } \\
I 0 \geq 55\end{array}$ & $\begin{array}{l}\text { Risperidone } 0.02 \mathrm{mg} / \mathrm{kg} \\
\text { v. placebo }\end{array}$ & 6 months & $\begin{array}{l}\text { DBD with N-CBRF conduct scale } \\
\text { scores } \\
\text { Symptom recurrence rate: } 42.3 \% \\
\text { placebo v. } 27.3 \% \text { risperidone } \\
\text { Hazard ratio } 2.24 \text { (95\% Cl } \\
1.54-3.28 \text { ) }\end{array}$ & $\begin{array}{l}\text { Weight gain }(3.2 \mathrm{~kg}) \text { and } \\
\text { somnolence }(11.6 \%) \text { with } \\
\text { risperidone } \\
\text { Infrequent EPS and prolactin- } \\
\text { related adverse events }\end{array}$ \\
\hline
\end{tabular}

ABC, Aberrant Behaviour Checklist; ADHD, attention-deficit hyperactivity disorder; BPI, Behaviour Problems Inventory; CGI, Clinical Global Impression scale; CGI-I, Clinical Global Impression scale - Improvement; DBD, disruptive behavioural disorder; EPS, extrapyramidal symptoms; N-CBRF, Nisonger-Child Behaviour Rating Form; RAAPP, Rating of Aggression Against People and/or Property scale.

\section{Obsessive-compulsive disorder}

The Pediatric OCD Treatment Study (POTS) Team (2004) found CBT to be an important component of treatment; however, further improvement was gained with the addition of an SSRI, sertraline. A recent review and meta-analysis (Watson 2008) demonstrated positive effects for CBT and medication in treating obsessive-compulsive disorder (OCD); however, there are no reported RCTs of antipsychotic augmentation with SSRIs in children and adolescents. A meta-analysis of nine studies of adults with treatment-resistant OCD (Bloch 2006) showed a significant absolute risk difference (ARD) of 0.22 (95\% CI 0.13-0.31) in favour of antipsychotic augmentation; those with comorbid tics had a particularly beneficial response $(\mathrm{ARD}=0.43,95 \% \mathrm{CI} 0.19-0.68)$.

\section{Anorexia nervosa}

Psychological interventions are the mainstay of treatment for eating disorders, and according to the NICE guidelines (National Collaborating Centre for Mental Health 2004) medication is not advocated for anorexia in any age group. There is some evidence for the use of olanzapine in adults with anorexia nervosa, but only 16 case reports have been published on its use in children and adolescents (Mehler-Wex 2008). The results of an RCT in adolescent females are awaited (Spettigue 2008). Case reports reveal positive psychopathological effects and good tolerability of quetiapine in children and adolescents with severe anorexia (Mehler-Wex 2008). In a small subset of patients with severe treatment-resistant anorexia, extreme weight phobia, delusional body image disturbances or severe hyperactivity, a trial of an SGA may be justified. Clearly, controlled studies are needed.

\section{Antipsychotics and pre-school children}

There is a growing literature, mainly from the USA, on the use of SGAs in the very young (under 5 years of age) for the treatment of bipolar disorder 
and aggression in autism. There is only limited evidence for such usage and the side-effect profile is even greater in this age group (Gleason 2007). If a decision is made to use this medication, it should be prescribed very cautiously and with careful monitoring alongside psychosocial interventions (see guidelines, Gleason 2007). Such practice is not licensed in the UK and is not recommended.

\section{Side-effects}

The side-effect profile of antipsychotics differs according to their receptor blockade potential (Correll 2006, 2008). There are important differences between SGAs and FGAs in terms of weight gain and metabolic syndrome, with perhaps more similarities than originally thought with respect to extrapyramidal side-effects and hyperprolactinaemia. The major side-effects (Table 5) are discussed below.

\section{Weight gain}

Weight gain with SGAs is greater in children and adolescents than in adults (Correll 2006). Excessive weight gain is associated with significant medical morbidity and mortality, including dyslipidaemia, diabetes mellitus, polycystic ovary syndrome, hypertension and sleep apnoea. The potential for weight gain, both in terms of the proportion of patients affected and amount of weight gained, is greatest with olanzapine and lower with quetiapine (Correll 2006). Weight gain is also low with aripiprazole (Findling et al, 2008) and ziprasidone.
There is some evidence from a recent metaanalysis that non-pharmacological interventions are effective in reducing weight gain in those prescribed antipsychotics (Álvarez-Jiménez 2008). A Cochrane review on the usefulness of switching antipsychotics is awaited (protocol: Mukundan 2007). Two RCTs (Klein 2006; Wu 2008), one in adolescents, point to the benefit of metformin as an adjunctive treatment. This is a cheap, easily administered drug and, apart from a risk of lactic acidosis in renal failure and chronic alcoholism, a safe treatment. Metformin leads to stabilisation of weight.

\section{Metabolic syndrome}

As a potential result of significant weight gain, SGAs have been associated with lipid abnormalities such as elevated triglyceride, total cholesterol and low-density lipoprotein (LDL) cholesterol levels, and/or decreased high-density lipoprotein (HDL) cholesterol levels in children and adolescents (Correll 2008). It is not clear how frequently metabolic syndrome - dyslipidaemia, glucose intolerance, hypertension and abdominal obesity - occurs in children and adolescents. The syndrome appears to result from insulin resistance secondary to weight gain.

The US Food and Drug Administration (FDA) has issued a 'black box' warning concerning the development of diabetes mellitus in patients receiving any SGAs. There have been case reports of new-onset diabetes in antipsychotic-treated

TABLE 5 Side-effect profile of second-generation antipsychotics and haloperidol (first-generation antipsychotic) ${ }^{\mathrm{a}}$

\begin{tabular}{|c|c|c|c|c|c|c|c|}
\hline Adverse effect & Aripiprazole & Clozapine & Olanzapine & Quetiapine & Risperidone & Ziprasidone & Haloperidol \\
\hline Anticholinergic & 0 & +++ & + & $0 /+$ & 0 & 0 & + \\
\hline Parkinsonian & $0 /+$ & 0 & + & 0 & ++ & + & +++ \\
\hline Akathisia & ++ & + & + & + & + & + & +++ \\
\hline Diabetes & $0 /+$ & +++ & +++ & ++ & + & $0 /+$ & $0 /+$ \\
\hline Raised lipids & $0 /+$ & ++ & +++ & + & + & $0 /+$ & $0 /+$ \\
\hline Weight gain & $0 /+$ & +++ & +++ & ++ & + & + & + \\
\hline Neutropenia & $0 /+$ & +++ & $0 /+$ & $0 /+$ & $0 /+$ & $0 /+$ & $0 /+$ \\
\hline Orthostasis & 0 & +++ & + & ++ & + & 0 & 0 \\
\hline Raised prolactin & 0 & 0 & 0 & 0 & +++ & $0 /+$ & +++ \\
\hline Lowered prolactin & ++ & 0 & 0 & 0 & 0 & 0 & 0 \\
\hline Increased QTc & 0 & $0 /+$ & 0 & + & 0 & ++ & +++ \\
\hline Sedation & 0 & +++ & ++ & ++ & $0 /+$ & $0 /+$ & + \\
\hline Seizure & $0 /+$ & ++ & $0 /+$ & $0 /+$ & $0 /+$ & $0 /+$ & $0 /+$ \\
\hline Tardive dyskinesia & 0 & 0 & $0 /+$ & $0 /+$ & $0 /+$ & $0 /+$ & + \\
\hline Withdrawal dyskinesia & $0 /+$ & 0 & $0 /+$ & $0 /+$ & + & + & + \\
\hline
\end{tabular}

0 , no side-effects; +, minor side-effects; ++, moderate side-effects; +++ severe side-effects

a. Includes some data from adult studies. 
children and adolescents. In an epidemiological study in New Zealand, the estimated incidence of diabetes mellitus was 4 cases per 1000 patient-years of treatment (95\% CI 0.5-15) (Harrison-Woolrych 2007). Risk factors for the development of diabetes include obesity, rapid weight gain, family history of diabetes and hyperlipidaemia (Correll 2008).

\section{Hyperprolactinaemia}

Secretion of prolactin from the pituitary is regulated by tonic dopaminergic inhibition. Consequently, the majority of FGAs and SGAs elevate prolactin levels. Hyperprolactinaemia can result in several side-effects: amenorrhoea and oligomenorrhoea, erectile dysfunction, decreased libido, hirsutism, and breast symptoms including galactorrhoea. Prolactin levels are not closely correlated with these symptoms. Hyperprolactinaemia appears dose dependent, tends to normalise over time, and resolves after antipsychotic discontinuation (Findling 2003). The relative potency of antipsychotic drugs to induce hyperprolactinaemia is greatest with risperidone and least with aripiprazole. If the patient develops persistently high prolactin levels, switching to a medication with a lower risk is often helpful. Aripiprazole may actually lower prolactin levels.

\section{Extrapyramidal side-effects}

Children and adolescents appear more sensitive than adults to extrapyramidal side-effects such as Parkinsonian side-effects and dystonia (Correll 2008). Although one study showed that the extrapyramidal side-effect rate was similar between FGAs and SGAs (Sikich 2004), the severity of extrapyramidal symptoms was greater with haloperidol. A review of extrapyramidal side-effects with risperidone in paediatric patients indicates a rate ranging from 8 to 26\% (Correll 2008). Clozapine (Kumra 1996; Shaw 2006) and quetiapine (DelBello 2002) appear to be associated with relatively low rates, as is the case in adults. Dose reduction or switching medication are the first lines of treatment, although oral or intramuscular anticholinergic medications can also be used.

\section{Neurological adverse events}

Fits

Children and adolescents taking clozapine may be at higher risk than adults for developing seizures or epileptiform discharges on an electroencephalogram (EEG) (Findling 2005). A pre-treatment EEG may be useful, and a repeat EEG when clinically indicated (i.e. overt or impending seizure activity, a daily dose of $600 \mathrm{mg}$ or blood level $>600 \mathrm{ng} / \mathrm{ml}$ ). Prophylactic treatment with an anticonvulsant (non-myelosuppressive) is sometimes necessary.

\section{Sedation and somnolence}

Sedation and somnolence are frequent side-effects that are usually dose dependent. Sedation rates range from 0 to 33\% for aripiprazole, and between 25 and $90 \%$ for risperidone, olanzapine and clozapine (Correll 2008). Somnolence appears to reduce with time due to developing tolerance.

\section{Neutropenia and agranulocytosis}

There is a risk of neutropenia and agranulocytosis with clozapine treatment, so regular monitoring is required. In a chart review of clozapine-treated paediatric in-patients (Gerbino-Rosen 2005), the cumulative 1-year probability of an initial adverse haematological event was $16.1 \%$ (neutropenia, $13 \%$; agranulocytosis, $0.6 \%$ ). However, $45 \%$ of the children and adolescents with newly emerging neutropenia were successfully re-challenged (under the supervision of a haematologist), and only $5 \%$ of patients discontinued clozapine because of agranulocytosis $(n=1)$ or neutropenia $(n=7)$. The adjunctive use of lithium to reduce neutropenia has been suggested (Sporn 2003), but it is not supported by all haematologists. Over time, the bone marrow seems to adjust and treatment can continue (Findling 2007). In general, specific monitoring is not required for other antipsychotics, except in patients with low baseline white blood cell counts.

\section{Cardiac effects}

\section{Myocarditis and cardiomyopathy}

Clozapine has been associated with a small risk for myocarditis, which occurs early on in treatment. A baseline electrocardiogram (ECG) is necessary. Blood pressure and pulse checks are initially performed daily to detect orthostatic changes and tachycardia. Some cardiomyopathies may be induced by tachycardia, and they can be avoided by early detection and appropriate dose adjustments and/or addition of a beta-blocker. Clozapine should be discontinued if either myocarditis or cardiomyopathy develops.

\section{QTc prolongation}

QTc prolongation (>430 ms) has been described in children and adolescents treated with ziprasidone (mean QTc prolongation $28 \mathrm{~ms}$, s.d. =26), which is unrelated to the dose of the drug (Blair 2005). Prolonged QTc is associated with a risk of cardiac arrest and sudden death (Hobbs 2006). 


\section{Assessment and monitoring}

The following tests and measurements are recommended at baseline and at regular 3-6 monthly follow-up intervals: weight, blood pressure, blood tests (full blood count at baseline only, except with clozapine, for which more regular monitoring is required), liver function tests, fasting lipids, cholesterol, blood sugar and prolactin (Correll 2008). Glucose, triglyceride and LDL cholesterol levels are strongly affected by eating, therefore fasting blood values should be used. Unfortunately, fasting glucose is a highly insensitive marker because the body compensates by increasing insulin levels before hyperglycaemia develops (Correll 2008). Ideally, measurement of insulin should be available. Haemoglobin A1c is an insensitive screening test, and therefore should only be used for monitoring in patients with diabetes. Prolactin levels should be measured while fasting in the morning, as prolactin levels vary during the day and can be elevated by food, exercise, stress, as well as medications (Correll 2008).

\section{Conclusions}

Fortunately, the evidence base for the use of antipsychotics in children and adolescents has increased with a number of RCTs now available. The quality of RCTs is variable, with problems of short duration, unclear allocation, selection bias and participant drop out. Many studies are funded by the pharmaceutical industry. In the majority, however, the statistical analyses with stated primary outcome measures and intentionto-treat analyses are an improvement. The evidence is reasonably strong for antipsychotics being effective in a number of disorders such as psychosis, pervasive developmental disorder, conduct disorder and bipolar disorder; however, the side-effect profile is concerning and requires continuous monitoring.

\section{Advantages and disadvantages}

There do not appear to be advantages of SGAs over FGAs in treating psychosis (Armenteros 2006; Kennedy 2007; Sikich 2008). Indeed, the weight gain and metabolic problems associated with SGAs raise important public health concerns given the widespread use of these medications (Sikich 2008). Caution is further heightened by the finding that, generally, side-effects in children and adolescents appear more severe than in adults (Correll 2008). The lower rate of tardive dyskinesia with SGAs (Corell 2007) is potentially an argument in favour of SGAs over FGAs. With the notable exception of clozapine, there is no evidence for greater efficacy of one antipsychotic over another in the treatment of psychosis in this age group, although a recent meta-analysis (Leucht 2009) for adult studies showed some superiority of olanzapine over aripiprazole, quetiapine, risperidone and ziprasidone. Choice may therefore be guided by the side-effect profile and the knowledge that the switching of antipsychotics is not backed by evidence (but see review by Buckley 2008).

Using higher than British National Formulary doses of antipsychotics does not appear effective (only indirect evidence for high-dose olanzapine is available: Kumra 2008) and such practice is not recommended. Indeed, a low-dose strategy is the norm in early-intervention psychosis practice. This is in line with findings from imaging studies which show a therapeutic antipsychotic response is achieved with $70 \% \mathrm{D}_{2}$-receptor blockade (Kapur 2000). Importantly, dosing should be more conservative for untreated new-onset patients than for those with multiple episodes (Berger 2008).

\section{Indications for treatment}

The increasing prescription of antipsychotics in children and adolescents needs to be examined critically. Although there are recognised indications, there is a danger that these medications will be used as first-line treatments, particularly if psychological treatments are not readily available, as for example in the case of conduct disorder (Doey 2007). This would be unfortunate and a potentially serious error given the side-effect profile of antipsychotics. Several measures might help: adoption of protocols which include reference to NICE guidelines; education for service users and parents; audit of clinicians' prescribing habits; and making psychological treatments more available and easier to implement. This does raise the question, however, of the relative effectiveness and indications for psychological and drug treatments. Unfortunately, information to help rational prescribing is not readily available. Indeed, there is a pressing need for RCTs of medication, psychological treatments and their combination. Such trials have already been very informative in cases of treating adolescent depression (March 2004; Goodyer 2007).

\section{Current recommendations}

The current recommendation is that antipsychotics should only be used as part of a comprehensive treatment plan, which involves psychoeducation and consideration of appropriate psychological and psychosocial interventions. Practising clinicians should be aware of the limited licensing for these medications. Clearly, further guidance backed by evidence is essential. 


\section{References}

Agrid 0, Remington G, Kapur S, et al (2007) Early use of clozapine for poorly responding first-episode psychosis. Journal of Clinical Psychopharmacology; 27: 369-73.

Álvarez-Jiménez M, Hetrick SE, González-Blanch C, et al (2008) Nonpharmacological management of antipsychotic-induced weight gain: systematic review and meta-analysis of randomised controlled trials. British Journal of Psychiatry; 193: 101-7.

Aman M, De Smedt G, Derivan A, et al (2002) Double-blind, placebocontrolled study of risperidone for the treatment of disruptive behaviors in children with subaverage intelligence. American Journal of Psychiatry; 159: 1337-46.

Armenteros J, Davies M (2006) Antipsychotics in early-onset schizophrenia. Systematic review and meta-analysis. European Journal of Child and Adolescent Psychiatry; 15: 141-8.

Bachmann C, Haberhausen M, Heizel-Gutenbrunner M, et al (2008) Large intraindividual variability of olanzapine serum concentrations in adolescent patients. Therapeutic Drug Monitoring; 30: 108-12.

Berger G, Proffitt T, McConchie M, et al (2008) Dosing quetiapine in drugnaive first-episode psychosis: a controlled, double-blind, randomized, single-center study investigating efficacy, tolerability, and safety of 200 $\mathrm{mg} /$ day vs. $400 \mathrm{mg} /$ day of quetiapine fumurate in 141 patients aged 15 to 25 years. Journal of Clinical Psychiatry; 69: 1702-14.

Bigos K, Pollock B, Coley K, et al (2008) Sex, race, and smoking impact olanzapine exposure. Journal of Clinical Pharmacology; 48: 157-65.

Blair J, Scahill L, State M, et al (2005) Electrocardiographic changes in children and adolescents treated with ziprasidone: a prospective study. Journal of the American Academy of Child and Adolescent Psychiatry; 44: 73-9.

Bloch M, Landeros-Weisenberger A, Kelmendi B, et al (2006) A systematic review: antipsychotic augmentation with treatment refractory obsessivecompulsive disorder. Molecular Psychiatry; 11: 622-32.

Buckley P, Correll C (2008) Strategies for dosing and switching for optimal clinical management. Journal of Clinical Psychiatry; 69 (suppl 1): 4-17.

Buitelaar JK, van der Gaag, Cohen-Kettenis P, et al (2001) A randomized controlled trial of risperidone in the treatment of aggression in hospitalized adolescents with subaverage cognitive abilities. Journal of Clinical Psychiatry; 62: 239-48.

Campbell M, Small A, Green W, et al (1984) Behavioral efficacy of haloperidol and lithium carbonate. A comparison in hospitalized aggressive children with conduct disorder. Archives of General Psychiatry; 41: $650-6$

Chavez B, Chavez-Brown M, Sopko Jr M, et al (2007) Atypical antipsychotics in children with pervasive developmental disorders. Paediatric Drugs; 9: 249-66.

Correll C, Carlson H (2006) Endocrine and metabolic adverse effects of psychotropic medications in children and adolescents. Journal of the American Academy of Child and Adolescent Psychiatry; 45: 771-91.

Correll C, Kane J (2007) One-year tardive dyskinesia rates in children and adolescents treated with second-generation antipsychotics: a systematic review. Journal of Child and Adolescent Psychopharmacology; 17: $647-55$.

Correll C (2008) Antipsychotic use in children and adolescents: minimizing adverse effects to maximize outcomes. Journal of the American Academy of Child and Adolescent Psychiatry; 47: 9-20.

DelBello M, Schwiers M, Rosenberg H, et al (2002) A double-blind, randomized, placebo-controlled study of quetiapine as adjunctive treatment for adolescent mania. Journal of the American Academy of Child and Adolescent Psychiatry; 41: 1216-23.

DelBello M, Kowatch R, Adler C, et al (2006) A double-blind randomized pilot study comparing quetiapine and divalproex for adolescent mania. Journal of the American Academy of Child and Adolescent Psychiatry; 45: 305-13.

Doey T, Handelman K, Seabrook J, et al (2007) Survey of atypical antipsychotic prescribing by Canadian child psychiatrists and developmental paediatricians for patients aged under 18 years. Canadian Journal of Psychiatry; 52: 363-8.
Engelhardt D, Polizos P, Waizer J, et al (1973) A double blind comparison of fluphenazine and haloperidol in outpatient schizophrenic children. Journal of Autism and Childhood Schizophrenia; 3: 128-37.

Faretra G, Dooher L, Dowling J (1970) Comparison of haloperidol and fluphenazine in disturbed children. American Journal of Psychiatry; 126: 1670-3.

Findling R, McNamara N, Branicky L, et al (2000) A double-blind pilot study of risperidone in the treatment of conduct disorder. Journal of the American Academy of Child and Adolescent Psychiatry; 39: 509-16.

Findling RL, Kusumakar V, Daneman D, et al (2003) Prolactin levels during long-term risperidone treatment in children and adolescents. Journal of Clinical Psychiatry; 64: 1362-9.

Findling RL, Steiner H, Weller EB (2005) Use of antipsychotics in children and adolescents. Journal of Clinical Psychiatry; 66: 29-40.

Findling R, Frazier J, Gerbino-Rosen G, et al (2007) Is there a role for clozapine in the treatment of children and adolescents? Journal of the American Academy of Child and Adolescent Psychiatry; 46: 423-8.

Findling R, Kauffman R, Sallee F, et al (2008) Tolerability and pharmacokinetics of aripiprazole in children and adolescents with psychiatric disorders: an open-label, dose escalation study. Journal of Clinical Psychopharmacology; 28: 441-6.

Gaffney G, Perry P, Lund B, et al (2002) Risperidone versus clonidine in the treatment of children and adolescents with Tourette's Syndrome. Journal of the American Academy of Child and Adolescent Psychiatry: 41: 330-6.

Gerbino-Rosen G, Roofeh D, Tompkins D, et al (2005) Hematological adverse events in clozapine-treated children and adolescents. Journal of the American Academy of Child and Adolescent Psychiatry; 44: 1024-31.

Gilbert D, Batterson J, Sethuraman G, et al (2004) Tic reduction with risperidone versus pimozide in a randomized, double-blind, crossover trial. Journal of the American Academy of Child and Adolescent Psychiatry; 43: 206-14.

Gleason M, Egger H, Emslie G, et al (2007) Psychopharmacological treatment for very young children: contexts and guidelines. Journal of the American Academy of Child and Adolescent Psychiatry; 46: 1532-72.

Gogtay N, Rapoport J (2008) Clozapine use in children and adolescents. Expert Opinion on Pharmacotherapy; 9: 459-65.

Goldberg T, Goldman R, Burdick K, et al (2007) Cognitive improvement after treatment with second-generation antipsychotic medications in first-episode schizophrenia: is it a practice effect? Archives of General Psychiatry; 64: 1115-22.

Goodyer I, Dubicka B, Wilkinson P, et al (2007) Selective serotonin reuptake inhibitors (SSRIs) and routine specialist care with and without cognitive behaviour therapy in adolescents with major depression: randomised controlled trial. BMJ; 335: 142.

Haas M, DelBello MP, Pandina G, et al (2009a) Risperidone for the treatment of acute mania in children and adolescents with bipolar disorder: a randomized, double-blind, placebo-controlled study. Bipolar Disorders; 11: 687-700.

Haas M, Eerdekens M, Kushner S, et al (2009b) Efficacy, safety and tolerability of two dosing regimes in adolescent schizophrenia: a doubleblind study. British Journal of Psychiatry; 194: 158-64

Harrison-Woolrych M, Garcia-Quiroga J, Ashton J, et al (2007) Safety and usage of atypical antipsychotic medicines in children: a nationwide prospective cohort study. Drug Safety; 30: 569-79.

Hobbs J, Peterson D, Moss A (2006) Risk of aborted cardiac arrest or sudden cardiac death during adolescence in the long-0T syndrome. JAMA; 296: 1249-54.

Hollander E, Wasserman S, Swanson E, et al (2006) A double-blind placebo-controlled pilot study of olanzapine in childhood/adolescent pervasive developmental disorder. Journal of Child and Adolescent Psychopharmacology; 16: 541-8.

Jensen S, Buitelaar J, Pandina G, et al (2007) Management of psychiatric disorders in children and adolescents with atypical antipsychotics: a systematic review of published clinical trials. European Child and Adolescent Psychiatry: 16: 104-20. 


\begin{tabular}{lllll}
\multicolumn{4}{l}{ MCO answers } \\
1 & 2 & 3 & 4 & 5 \\
af & at & af & af & af \\
bf & bf & bf & bt & bf \\
cf & cf & cf & cf & ct \\
dt & df & df & df & df \\
ef & ef & et & ef & ef
\end{tabular}

Kafantaris V, Coletti D, Dicker R, et al (2001) Adjunctive antipsychotic treatment of adolescents with bipolar psychosis. Journal of the American Academy of Child and Adolescent Psychiatry; 40: 1448-56.

Kapur S, Zipursky R, Jones C, et al (2000) Relationship between dopamine $\mathrm{D}(2)$ occupancy, clinical response, and side-effects: a double-blind PET study of first-episode schizophrenia. American Journal of Psychiatry; 157 : $154-20$

Kapur S (2003) Psychosis as a state of aberrant salience: a framework linking biology, phenomenology, and pharmacology in schizophrenia. American Journal of Psychiatry; 160: 13-23

Kennedy E, Kumar A, Datta SS (2007) Antipsychotic medication for childhood-onset schizophrenia. Cochrane Database of Systematic Reviews; issue 3: CD004027

Klein D, Cottingham E, Sorter M, et al (2006) A randomized, doubleblind, placebo-controlled trial of metformin treatment of weight gain associated with initiation of atypical antipsychotic therapy in children and adolescents. American Journal of Psychiatry; 163: 2072-9

Kowatch RA, Fristad M, Birmaher B, et al (2005) Treatment guidelines for children and adolescents with bipolar disorder. Journal of the American Academy of Child and Adolescent Psychiatry; 44: 213-35.

Kryzhanovskaya L, Schulz S, McDougle C, et al (2009) Olanzapine versus placebo in adolescents with schizophrenia: a 6-week, randomized doubleblind, placebo-controlled trial. Journal of the American Academy of Child and Adolescent Psychiatry; 48: 60-70.

Kumra S, Frazier J, Jacobsen L, et al (1996) Childhood-onset schizophrenia: a double-blind clozapine-haloperidol comparison. Archives of General Psychiatry; 53: 1090-7

Kumra S, Kranzler H, Gerbino-Rosen G, et al (2008) Clozapine and 'highdose' olanzapine in refractory early-onset schizophrenia: a 12-week randomized and double-blind comparison. Biological Psychiatry; 63 : $524-9$

Leucht S, Komossa K, Rummel-Kluge C, et al (2009) A meta-analysis of head-to-head comparisons of second-generation antipsychotics in the treatment of schizophrenia. American Journal of Psychiatry; 166: $152-63$

Lewis S, Lieberman J (2008) CATIE and CUtLASS: can we handle the truth? British Journal of Psychiatry; 192: 161-3.

Luby J, Mrakotsky C, Stalets MM, et al (2006) Risperidone in preschool children with autistic spectrum disorders: an investigation of safety and efficacy. Journal of Child and Adolescent Psychopharmacology; 16: $575-87$

March J, Silva S, Petrycki S, et al (2004) Fluoxetine, cognitive-behaviora therapy, and their combination for adolescents with depression: Treatment for Adolescents With Depression Study (TADS) randomized controlled trial. JAMA; 292: 807-20.

McCracken J, McGough J, Shah B, et al (2002) Risperidone in children with autism and serious behavioral problems. New England Journal of Medicine; 347: 314-21.

McDougle C, Scahill L, Aman MG, et al (2005) Risperidone for the core symptom domains of autism: results from the study by the Autism Network of the Research Units on Pediatric Psychopharmacology. American Journal of Psychiatry; 162: 1142-8.

Medicines and Healthcare products Regulatory Agency (2007) Medicine for children. MHRA (http://www.mhra.gov.uk/Howweregulate/Medicines/ Medicinesforchildren/index.htm).

Mehler-Wex C, Romanos M, Kirhheimer J, et al (2008) Atypical antipsychotics in severe anorexia nervosa in children and adolescents review and case reports. European Eating Disorders Review, 16: 100-8.

Miral S, Gencer 0, Inal-Emiroglu F, et al (2008) Risperidone versus haloperidol in children and adolescents with $\mathrm{AD}$ : a randomized, controlled, double-blind trial. European Child and Adolescent Psychiatry; 17: 1-8.

Morgan S, Taylor E (2007) Antipsychotic drugs in children with autism. BMJ: 334: 1069-70.

Mukundan A, Faulkner G, Cohn T, et al (2007) Antipsychotic switching for people with schizophrenia who have neuroleptics induced weight or metabolic problems (Protocol). Cochrane Database of Systematic Reviews; issue 3: CD006629.
Nagaraj R, Singhi P, Malhi P (2006) Risperidone in children with autism: randomized, placebo-controlled, double-blind study. Journal of Child Neurology; 21: 450-5.

National Collaborating Centre for Mental Health (2002) Schizophrenia Atypical Antipsychotics. National Institute for Health and Clinical Excellence (http://www.nice.org.uk/guidance/index.jsp?action=bylD\&0=11460)

National Collaborating Centre for Mental Health (2004) Eating Disorders: Core Interventions in the Treatment of Anorexia Nervosa, Bulimia Nervosa, and Related Eating Disorders. National Institute for Health and Clinical Excellence (http://www.nice.org.uk/nicemedia/pdf/cg009niceguidance. pdf).

National Institute for Health and Clinical Excellence (2005) Latest NICE guidance sets new standards for treating depression in children and young people. NICE (http://www.nice.org.uk/guidance/index. isp?action=download\&0=29862

National Institute for Health and Clinical Excellence (2006) Conduct disorders in children - new guidance to help parents. NICE (http:// www.nice.org.uk/newsroom/guidanceinfocus/conduct disorders in children_new_guidance_to_help_parents.jsp).

Olfson M, Blanco C, Liu L, et al (2006) National trends in the outpatient treatment of children and adolescents with antipsychotic drugs. Archives of General Psychiatry; 63: 679-85.

Pediatric OCD Treatment Study (POTS) Team (2004) Cognitive-behavior therapy, sertraline, and their combination for children and adolescents with obsessive-compulsive disorder: the Pediatric OCD Treatment Study (POTS) randomized controlled trial. JAMA: 292: 1969-76.

Pool D, Bloom W, Mielke D, et al (1976) A controlled evaluation of loxitane in seventy-five adolescent schizophrenic patients. Current Therapeutic Research, Clinical and Experimental; 19: 99-104.

Realmuto G, Erickson W, Yellin A et al (1984) Clinical comparison of thiothixene and thioridazine in schizophrenic adolescents. American Journal of Psychiatry; 141: 440-2.

Reyes M, Buitelaar J, Toren P, et al (2006) A randomized, double-blind, placebo-controlled study of risperidone maintenance treatment in children and adolescents with disruptive behavior disorders. American Journal of Psychiatry; 163: 402-10.

Sallee F, Nesbitt L, Jackson C, et al (1997) Relative efficacy of haloperidol and pimozide in children and adolescents with Tourette's disorder. American Journal of Psychiatry; 154: 1057-62.

Sallee F, Kurlan R, Goetz C, et al (2000) Ziprasidone treatment of children and adolescents with Tourette's syndrome: a pilot study. Journal of the American Academy of Child and Adolescent Psychiatry: 39: 292-9.

Sanford M, Keating G (2007) Aripiprazole in adolescents with schizophrenia. Paediatric Drugs; 9: 419-23.

Scahill L, Leckman J, Schultz R, et al (2003) A placebo-controlled trial of risperidone in Tourette syndrome. Neurology; 60: 1130-5.

Shaw P, Sporn A, Gogtay N, et al (2006) Childhood-onset schizophrenia: a double-blind, randomized clozapine-olanzapine comparison. Archives of General Psychiatry; 63: 721-30.

Shea S, Turgay A, Carroll A, et al (2004) Risperidone in the treatment of disruptive behavioral symptoms in children with autistic and other pervasive developmental disorders. Pediatrics; 114: e634-41.

Shelton R, Papakostas G (2008) Augmentation of antidepressants with atypical antipsychotics for treatment-resistant major depressive disorder. Acta Psychiatrica Scandinavica; 117: 253-9.

Sikich L, Hamer R, Bashford R, et al (2004) A pilot study of risperidone, olanzapine, and haloperidol in psychotic youth: a double-blind, randomized, 8-week trial. Neuropsychopharmacology; 29: 133-45

Sikich L, Frazier J, McClellan J, et al (2008) Double-blind comparison of first- and second-generation antipsychotics in early-onset schizophrenia and schizo-affective disorder: findings from the treatment of early-onset schizophrenia spectrum disorders (TEOSS) study. American Journal of Psychiatry; 165: 1420-31.

Snyder R, Turgay A, Aman M, et al (2002) Effects of risperidone on conduct and disruptive behavior disorders in children with subaverage IOs. Journal of the American Academy of Child and Adolescent Psychiatry; 41: 102636 
Spencer E, Kafantaris V, Padron-Gayol M, et al (1992) Haloperidol in schizophrenic children: early findings from a study in progress. Psychopharmacology Bulletin; 28: 183-6.

Sporn A, Vermani A, Greenstein D, (2007) Clozapine treatment of childhood-onset schizophrenia: evaluation of effectiveness, adverse effects, and long-term outcome. Journal of the American Academy of Child and Adolescent Psychiatry; 46: 1349-56.

Spettigue W, Buchholz A, Henderson K, et al (2008) Evaluation of the efficacy and safety of olanzapine as an adjunctive treatment for anorexia nervosa in adolescent females: a randomized, double-blind, placebocontrolled trial. BMC Pediatrics; 8: 4.

Sporn A, Gogtay N, Ortiz-Aguavo R, et al (2003) Clozapine-induced neutropenia in children: management with lithium carbonate. Journal of Child and Adolescent Psychopharmacology; 13: 401-4.

Tohen M, Kryzhanovskaya L, Carlson G, et al (2007) Olanzapine versus placebo in the treatment of adolescents with bipolar mania. American Journal of Psychiatry; 164: 1547-56.

Troost P, Lahuis B, Steenhuis MP, et al (2005) Long-term effects of risperidone in children with autism spectrum disorders: a placebo discontinuation study. Journal of the American Academy of Child and Adolescent Psychiatry; 44: 1137-44.

Van Bellighen M, De Troch C (2001) Risperidone in the treatment of behavioral disturbances in children and adolescents with borderline intellectual functioning: a double-blind, placebo-controlled pilot trial. Journal of Child and Adolescent Psychopharmacology; 11: 5-13.

Watson J, Rees C (2008) Meta-analysis of randomized, controlled treatment trials for pediatric obsessive-compulsive disorder. Journal of Child Psychology and Psychiatry; 49: 489-98.

Wu RR, Zhao JP, Guo XF, et al (2008) Metformin addition attenuates olanzapine-induced weight gain in drug-naive first-episode schizophrenia patients: a double-blind, placebo-controlled study. American Journal of Psychiatry; 165: 352-8.

Xiong Y (2004) Comparison study of childhood schizophrenia treated with risperidone and chlorpromazine. Guizhou Medical Journal; 28 : $697-8$.

Yao $\mathrm{H}$ (2003) A study of risperidone in the treatment of child schizophrenia. Journal of Clinical Psychological Medicine; 7468: 801

\section{MCQs}

1 The prescription of antipsychotics in children and adolescents in the USA has:

a remained fairly static since 1999

b decreased alongside the use of psychosocial treatments

c increased only marginally

d increased over sixfold between 1999 and 2002

e reduced dramatically following FDA warnings.

\section{Weight gain as a side-effect of antipsychotic medication:}

a is more frequent in children and adolescents

$\mathrm{b}$ is more frequent with FGAs

c is of only marginal significance

d occurs equally with all SGAs

$\mathrm{e}$ is more frequent in adults.
3 Raised prolactin levels:

a are seen with all SGAs

b are due to a peripheral effect of antipsychotics

c continue to rise with continued use of antipsychotic medication

d are irreversible

e can lead to sexual side-effects.

\section{Clozapine:}

$\mathrm{a}$ is not recommended for children and adolescents under 18 years

b is more effective that other antipsychotics in children and adolescents

c is not associated with serious side-effects in children and adolescents

$d$ is recommended as a first-line treatment for schizophrenia e unlike other antipsychotics is not associated with weight gain.

5 For children and adolescents with autism, antipsychotic medication:

a is recommended routinely to treat core deficits

$\mathrm{b}$ is not associated with adverse side-effects

c has been shown to reduce irritability

d should be used without other psychosocial interventions

$\mathrm{e}$ is not used owing to the lack of research evidence. 